RAD Conference Proceedings, vol. 2, pp. 48-54, 2017

www.rad-proceedings.org

novororitty

\title{
BACKGROUND DOUBLE COINCIDENCES AT A MULTIDETECTOR GAMMA SPECTROMETER
}

\author{
Nevenka M. Antović ${ }^{*}$, Sergey K. Andrukhovich², Nikola Svrkota3 \\ ${ }^{1}$ Faculty of Natural Sciences and Mathematics, University of Montenegro, Podgorica, Montenegro \\ ${ }^{2}$ B. I. Stepanov Institute of Physics, National Academy of Sciences of Belarus, Minsk, Belarus \\ ${ }^{3}$ Centre for Ecotoxicological Research, Podgorica, Montenegro
}

\begin{abstract}
Double background coincidences at two multidetector spectrometers, which have 6 and $32 \mathrm{NaI}(\mathrm{Tl})$ detectors and registration geometry close to $4 \pi$ (PRIPYAT-2M and ARGUS), are considered as a sum of true and random ones. They have been analyzed together with the energy resolution and efficiency of ${ }^{137} \mathrm{Cs},{ }^{6} \mathrm{ZZn}$ and ${ }^{40} \mathrm{~K}$ (photons with energy of $662 \mathrm{keV}, 1116 \mathrm{keV}$ and $1461 \mathrm{keV}$, respectively) detection in the full absorption peak (individual detectors and the whole spectrometers). The number of detector-duplet combinations registering double coincidences was 15 and 496, respectively (an angle from the spectrometer centers to the detecor centers ranged from $37.38^{\circ}$ to $\sim 180^{\circ}$ ). Double background coincidences in the whole energy range in dependence on the detector arrangement, as well as double coincidences caused by monoenergetic sources in the whole energy range, showed that main contributors to the background double coincidences at the spectrometers PRIPYAT and ARGUS are coinciding photons, which were scattered from detector to detector. In the 32-detector system, the minimum, maximum, arithmetic mean and standard deviation of the background double coincidences counting rates in the whole energy range were found to be 0.034 (detector pairs at $\left.79.19^{\circ}\right)$, o.142 $\left(37.38^{\circ}\right.$ ), o.o66, o.o33 cps, respectively. The same values for the background double coincidences counting rates coming from monoenergetic sources were 0.974 $\left(63.43^{\circ}\right), 4.646\left(41.81^{\circ}\right), 3.0724,1.167 \mathrm{cps}$, respectively $\left({ }^{137} \mathrm{Cs}\right)$, and $0.389\left(63.43^{\circ}\right), 18.706\left(\sim 180^{\circ}\right), 2.794,5.294 \mathrm{cps}$, respectively $\left({ }^{6} \mathrm{ZZn}\right)$, while for the background double coincidences counting rates in the photo-peak regions - o.oo3 $\left(63.43^{\circ}\right), 0.0114\left(41.81^{\circ}\right), 0.0074,0.0029 \mathrm{cps}$, respectively (region $\left.662 \mathrm{keV}\right)$, and $0.0056\left(63.43^{\circ}\right), 0.0241\left(37.38^{\circ}\right)$, 0.0148 , $0.006 \mathrm{cps}$, respectively (region $1116 \mathrm{keV}$ ). In the 6-detector system, average counting rates of the background double coincidences in the whole energy range were $0.539 \mathrm{cps}\left(90^{\circ}\right)$ and $0.544 \mathrm{cps}\left(180^{\circ}\right)$, those of the double

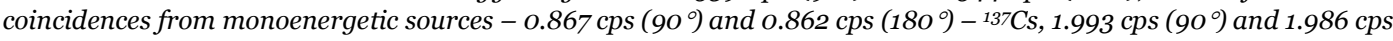
$\left(180^{\circ}\right)-40 \mathrm{~K}$, and those of the background double coincidences in the photo-peak regions $-0.0825 \mathrm{cps}\left(90^{\circ}\right)$ and $0.0749 \mathrm{cps}\left(180^{\circ}\right)$ - region $662 \mathrm{keV}, 0.0426 \mathrm{cps}\left(90^{\circ}\right)$ and $0.0428 \mathrm{cps}\left(180^{\circ}\right)$ - region $1461 \mathrm{keV}$.
\end{abstract}

Key words: Multidetector spectrometer, background, double coincidences, Cs-137, Zn-65, K-4O

DOI: $10.21175 /$ RadProc.2017.11

\section{INTRODUCTION}

Multidetector systems are often used for a coincidence registration of gamma rays. Signals coming from detectors should be overlapped in time, i.e. detectors should register photons simultaneously (respecting the system's resolving time). The total counting rate is generally equal to a sum of counting rates of true and random coincidences. True coincidences are events from the same decay act, as random ones - events without the common genetic origin. A counting rate of random coincidences can be evaluated using the system's resolving time and counting rates of individual detectors [1]. So, in the analysis of true coincidences, random ones should be subtracted from the total number of coincidences, as well as background.

The counting rate of background coincidences is also a sum of true and random ones. It can be assumed that scattering of photons from one detector to other in a multidetector spectrometer gives contribution to the background spectra, particularly of double coincidences, when two detectors register events satisfying the condition of simultaneity.

In contrast to the Compton-suppression spectrometers (e.g. HPGe as central, registering photons in the full absorption peak, and $\mathrm{NaI}(\mathrm{Tl})$ detectors working in the anti-coincidence mode with the central detector, as an active shield), in spectra of the multidetector systems working in coincidence modes and containing $\mathrm{NaI}(\mathrm{Tl})$ detectors, contribution of scattered photons could be significant. Although these systems have advantages in compare to an HPGe spectrometer (shorter measuring time, better sensitivity, various counting modes, etc.), and often are suitable for research on rare nuclear decays, i.e., rare nuclear phenomena, photons scattering may have an influence on the analysis precision. This is because, due to the Compton scattering, processes imitating investigated phenomenon could appear (see, for

\footnotetext{
*antovicn@yahoo.com
} 
example, [2]). Therefore, the effect consideration, corrections and sometimes additional measures (such as collimation) to reduce contribution of the scattered radiation to the coincidence spectra (i.e., regions of interest) are needed.

This paper is aimed to consider background double coincidences registered by two multidetector gamma spectrometers, in dependence on angle between $\mathrm{NaI}(\mathrm{Tl})$ detectors and photon energy.

Double coincidences from ${ }^{137 \mathrm{Cs},}{ }^{65 \mathrm{Zn}}$ and $40 \mathrm{~K}$ (photons with energy of $662 \mathrm{keV}, 1116 \mathrm{keV}$ and 1461 $\mathrm{keV}$, respectively) have been considered in the spectra obtained using two spectrometers developed at the B. I. Stepanov Institute of Physics, National Academy of Sciences of Belarus in Minsk: with 6 (PRIPYAT-2M, located at the Faculty of Natural Sciences and Mathematics, University of Montenegro, Podgorica) and 32 (ARGUS, B. I. Stepanov Institute of Physics, Minsk) $\mathrm{NaI}(\mathrm{Tl})$ detectors, with geometry of registration close to $4 \pi$, and results are presented here.

$\mathrm{K}-40$ is naturally occurring (half-life: $1.277 \cdot 10^{9} \mathrm{y}$ ), while ${ }^{137} \mathrm{Cs}$ (fission product) and ${ }^{65 \mathrm{Zn}}$ (half-lives: $30.7 \mathrm{y}$ and $244.26 \mathrm{~d}$, respectively) are artificial, with a mode of production - neutron activation (thermal and fast neutrons) [3]. All of them are one-cascade gamma emitters, and can be considered as monoenergetic (taking into account the emitted photon's intensity). K40 decays to the ground state of ${ }^{\circ} \mathrm{Ca}$ (via $\beta^{-}, 89.3 \%$ ) and to ${ }^{40} \mathrm{Ar}$ (EC and $\beta^{+}, 10.7 \%$ ) - accompanied by the emission of the $1460.83 \mathrm{keV}$ photon [3]. The decay of ${ }^{6} \mathrm{Zn}$ to ${ }^{65} \mathrm{Cu}\left(\mathrm{EC}\right.$ and $\left.\beta^{+}\right)$is accompanied by the emission of three photons, but two of them $(344.95 \mathrm{keV}$ and $770.6 \mathrm{keV}$ ) have extremely low intensities (0.003 \%) [3]. Therefore, a registration of this radionuclide is based on the $1115.546 \mathrm{keV}$ (50.6 \%) gamma ray detection. The beta-minus decay of ${ }^{137} \mathrm{Cs}$ to ${ }^{137} \mathrm{Ba}$ is accompanied by the emission of two photons (deexcitation of ${ }^{137} \mathrm{Ba}$ ), but one of them is dominant (661.657 keV, 85.1\%). Another one (283.53 keV) has an intensity of around $0.0006 \%$ [3] and cannot be used for a standard ${ }^{137} \mathrm{Cs}$ registration.

\section{SPECTROMETERS}

\subsection{Detector-duplets}

Spectrometer ARGUS [4] - a Crystal Ball spectrometer containing $32 \mathrm{NaI}(\mathrm{Tl})$ detectors, together with a block diagram showing the operation mode, was described previously (see, for example, $[5,6]$ ). Full coverage for all the scintillation units is close to $4 \pi$ $(\sim 0.9 \cdot 4 \pi \mathrm{sr})$, and time resolution for double coincidences is $45 \mathrm{~ns}$. The majority coincidence circuit and spectrometer software enabled registering and analyzing $k$-fold coincidences $(\mathrm{k}=1-5)$.

The number of ARGUS detector pairs capable of registering double gamma coincidences, is shown in Table 1. As commented in Ref. [5], the disc shaped leaden collimators were mounted on each detector (with thickness and diameter of 30 and $150 \mathrm{~mm}$, respectively) to reduce Compton scattering, i.e., to reduce a contribution of the background coincidences, as well as background in general (considered in the same and cited references). Spectral data obtained before introducing collimators into the ARGUS system are presented in this work, i.e., previously acquired spectra of two sources $-{ }^{137 \mathrm{Cs}}(82200 \mathrm{~Bq})$ and ${ }^{6} \mathrm{Zn}$ (22 800 Bq).

The PRIPYAT-2M spectrometer [7] with six NaI(Tl) scintillation detectors (150 $\mathrm{mm} \times 100 \mathrm{~mm})$ - shown in Fig. 1, and full coverage close to $4 \pi(\sim 0.7 \cdot 4 \pi \mathrm{sr})$ and resolution time for coincidences of $40 \mathrm{~ns}$, contains detector pairs able to register double gamma coincidences as shown in Table 2. The spectrometer counts $k$-fold coincidences $(\mathrm{k}=1-6)$.

Table 1. Number of the ARGUS detector-duplet combinations registering double gamma coincidences

\begin{tabular}{|c|c|}
\hline $\begin{array}{c}\text { Angle } \\
\left({ }^{\circ}\right)\end{array}$ & $\begin{array}{c}\text { Number of the } \\
\text { detector-duplets in the } \\
\text { spectrometer ARGUS } \\
(\mathrm{n})\end{array}$ \\
\hline 37.38 & 60 \\
\hline 41.81 & 30 \\
\hline 63.43 & 30 \\
\hline 70.53 & 60 \\
\hline 79.19 & 60 \\
\hline 100.81 & 60 \\
\hline 109.47 & 60 \\
\hline 116.57 & 30 \\
\hline 138.19 & 30 \\
\hline 142.62 & 60 \\
\hline$\sim 180$ & 16 \\
\hline
\end{tabular}

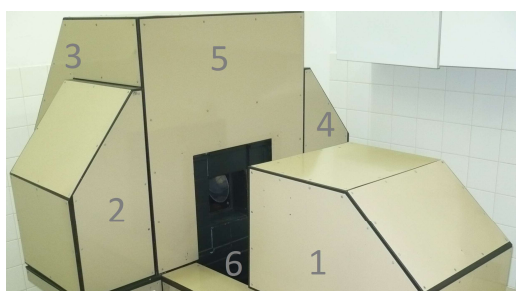

Figure 1. Detector units of the PRIPYAT-2M spectrometer

Table 2. Number of the PRIPYAT-2M detector-duplet combinations registering double gamma coincidences

\begin{tabular}{|c|c|}
\hline $\begin{array}{c}\text { Angle } \\
\left({ }^{\circ}\right)\end{array}$ & $\begin{array}{c}\text { Number of the } \\
\text { detector-duplets in the } \\
\text { spectrometer PRIPYAT } \\
(\mathrm{n})\end{array}$ \\
\hline$\sim 90$ & 12 \\
\hline$\sim 180$ & 3 \\
\hline
\end{tabular}

Cs-137 and ${ }^{40} \mathrm{~K}$ measured by the PRIPYAT-2M spectrometer were calibration standards of the VNIIM D.I. Mendeleev (137Cs: OMASN, N.72/94-2, $870 \mathrm{~Bq}-$ January 01, 1994; 40K: OMASN, N.109/92, 9.10³ Bq August 01, 1992).

\subsection{Detection efficiency and energy resolution}

Efficiencies of detection of ${ }^{137 \mathrm{Cs},}{ }^{65 \mathrm{Zn}}$ and ${ }^{40} \mathrm{~K}$ (photons with energies $662 \mathrm{keV}, 1116 \mathrm{keV}$ and $1461 \mathrm{keV}$, respectively) in the full absorption peak (photo-efficiencies) for individual detectors of the ARGUS and PRIPYAT spectrometer are shown in Fig. 2 ((a) and (b), respectively). These photons do not participate in any cascade, and can be registered in 
photo-peak only in an integral or non-coincidence $(\mathrm{k}=1)$ mode of counting.

Detection efficiencies for the $662 \mathrm{keV}$ photon $\left({ }^{137 \mathrm{Cs})}\right.$ at the ARGUS spectrometer in the energy range (2001500) $\mathrm{keV}$ were previously analyzed [8], and those data are used for a comparison with the PRIPYAT-2M ones.

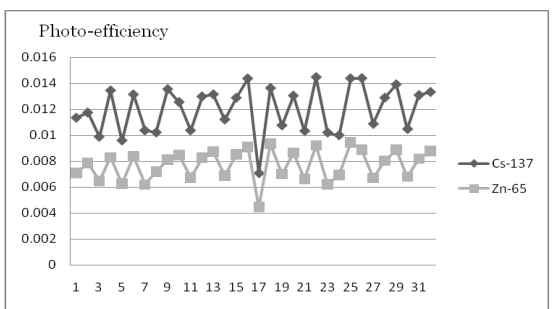

a)

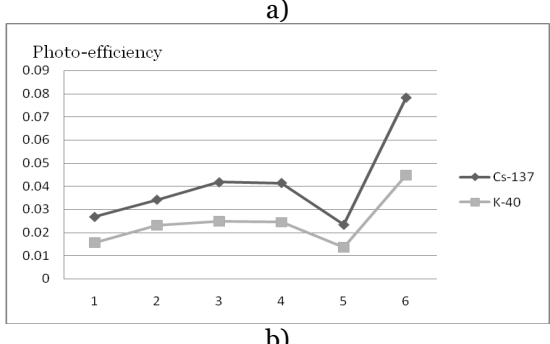

b)

Figure 2. Photo-efficiencies of the individual detectors: ARGUS (a), PRIPYAT-2M (b)

The photo-efficiency of individual detectors in the 32-detector system (ARGUS) ranged from 0.007062 to 0.014471 , with an average of $0.011986(662 \mathrm{keV})$, and from 0.004475 to 0.009448 , with an average of 0.007709 (1116 keV).

Individual photo-efficiencies in the 6-detector system (PRIPYAT-2M) determined experimentally in the non-coincidence mode of counting from the photopeak counts (based on peak counting rate, photon intensity and the source activity), showed an average of 0.041 for the $662 \mathrm{keV}$ and 0.024 for the $1461 \mathrm{keV}$ photons. Photo-efficiencies of the whole spectrometers (obtained from sum spectra) are given in Table 3, with “*” referring the energy range from 200 to $2000 \mathrm{keV}$. The PRIPYAT sum non-coincident spectra (500 $\mathrm{s}$ real measuring time, from 2 to 255 channel) of ${ }^{137 \mathrm{Cs}}$ in the energy range from 200 to $1500 \mathrm{keV}$ and from 200 to $2000 \mathrm{keV}$, as well as ${ }^{\circ} \mathrm{K}$ in the energy range (2002000) $\mathrm{keV}$, after background subtraction, are given in Fig. 3. The detection efficiency of the $662 \mathrm{keV}\left({ }^{137} \mathrm{Cs}\right)$ in the case of the PRIPYAT spectrometer is by a factor of 1.7 lower than that of the ARGUS system, in the same energy range.

The energy resolution $\left(\Delta \mathrm{E}_{\gamma} / \mathrm{E}_{\gamma}, \%\right)$ for individual detectors is shown in Fig. 4, as that for whole spectrometers in Table 3 .

Individual energy resolutions in the 32-detector system (ARGUS), in the energy range from 200 to $1500 \mathrm{keV}$, ranged from 9.4 to $20.5 \%$, with an average of $12.9 \%$ (662 keV), and from 8 to $19.8 \%$, with an average of $11.0 \%(1116 \mathrm{keV})$. The energy resolution of individual detectors in the 6-detector system (PRIPYAT-2M) ranged from $7.5 \%$ to $10.7 \%$, with an average of $9.5 \%(662 \mathrm{keV})$, and from $5.3 \%$ to $10.7 \%$, with an average of $7.7 \%(1461 \mathrm{keV})$.
Table 3. Photo-efficiency and energy resolution obtained from sum spectra

\begin{tabular}{|cccc|}
\hline $\begin{array}{c}\text { Photon energy } \\
(\mathrm{keV})\end{array}$ & $\varepsilon$ & Spectrometer & $\begin{array}{c}\Delta \mathrm{E}_{\gamma} / \mathrm{E}_{\gamma} \\
(\%)\end{array}$ \\
\hline 662 & 0.38 & ARGUS & \\
1116 & 0.25 & & 12.9 \\
662 & & PRIPYAT & 11.0 \\
\hline & 0.227 & & 15.4 \\
1461 & $0.233^{*}$ & & $13.9^{*}$ \\
\hline
\end{tabular}

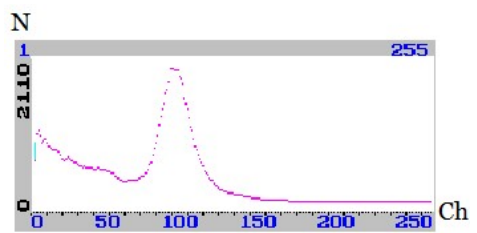

a)

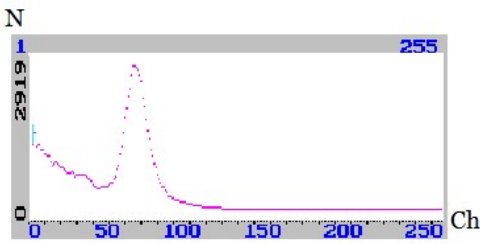

b)

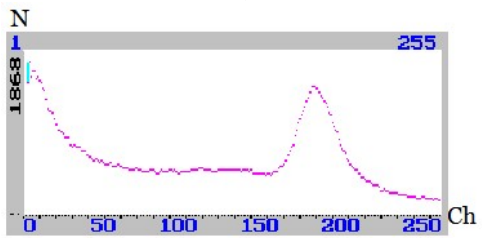

c)

Figure 3. Sum spectra of the PRIPYAT-2M spectrometer ( $\mathrm{N}$-counts, $\mathrm{Ch}$ - channel): ${ }^{137} \mathrm{Cs}$ in the range (200-1500) keV (a), ${ }^{137} \mathrm{Cs}$ in the range $(200-2000) \mathrm{keV}(\mathrm{b}),{ }^{\circ} \mathrm{K}$ in the range (200-2000) $\mathrm{keV}(\mathrm{c})$

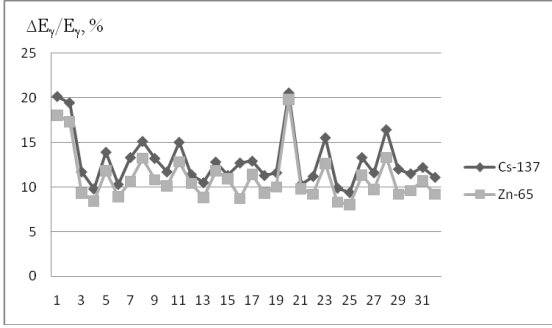

a)

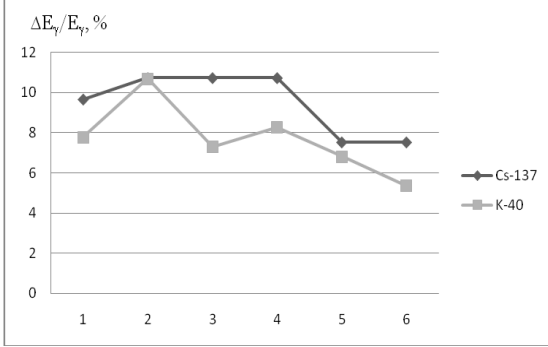

b)

Figure 4. Energy resolutions of the individual detectors: ARGUS (a), PRIPYAT-2M (b) 


\section{BACKGROUND DOUBLE GAMMA COINCIDENCES}

It is known that the background, in the case of $\mathrm{NaI}(\mathrm{Tl})$ detectors, comes from cosmic radiation, radiation of radionuclides from environment $\left(4^{\circ} \mathrm{K}\right.$ and decay products of uranium and thorium), as well as radiation from radionuclides in scintilation unit itself ( ${ }^{\circ} \mathrm{K}$ in photomultiplier glass).

In order to reduce the background, the ARGUS and PRIPYAT were constructed from low-background materials, and their detecting systems are shielded (ARGUS: cellar room, low background concrete $20 \mathrm{~cm}$ below, lead $-14 \mathrm{~cm}$ below and $7 \mathrm{~cm}$ on the sides); PRIPYAT (Fig. 1): iron and lead up to $15 \mathrm{~cm}$ ). On the other hand, an effective mean for reducing the background in this type of detection systems is a work in a coincidence mode of counting. Although the coincidence modes suppress the background significantly [9], random coincidences of photons and particularly Compton scattering - give a contribution, i.e., the background coincidences. Among them, double coincidences are the most intense.

A background spectrum of the ARGUS spectrometer in the energy range from 200 to $1500 \mathrm{keV}$ in the mode of double coincidences was given previously [5].

The sum background spectrum $(500 \mathrm{~s}$ real measuring time) in the mode of double coincidences at the PRIPYAT-2M spectrometer (in the energy range from 200 to $1500 \mathrm{keV}$ and from 200 to $2000 \mathrm{keV}$ ), is shown in Fig. 5. Somewhat higher counting rate in the range from 200 to $2000 \mathrm{keV}$ can be explained by the detection of gamma rays from natural radionuclides, such as the $1764 \mathrm{keV}$ photons from ${ }^{214} \mathrm{Bi}$ (in ${ }^{238 \mathrm{U} /{ }^{226} \mathrm{Ra}}$ series) with an intensity of $15.4 \%$ [3].

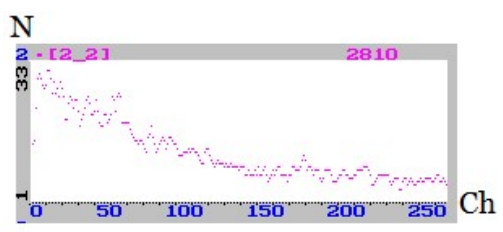

a)

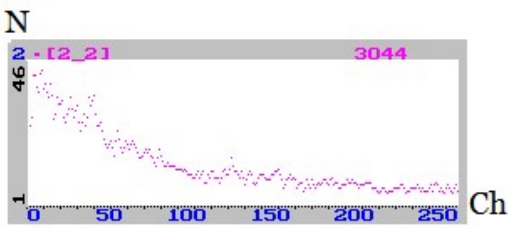

b)

Figure 5. Sum background spectrum of the PRIPYAT-2M in the mode of double coincidences $(\mathrm{N}$ - counts, $\mathrm{Ch}$ - channel): (200-1500) keV (a), (200-2000) keV (b)

Looking at the PRIPYAT system configuration (Fig. 1), detector pairs registering double coincidences are 12, 14, 15, 16, 23, 25, 26, 34, 35, 36, 45, $46\left(90^{\circ}\right)$, and $13,24,56\left(180^{\circ}\right)$. An average counting rate of these detector pairs is further analyzed.

The results of double background coincidences analysis at the ARGUS spectrometer in the whole energy range are shown in Fig. 6. The counting rates (N) were calculated as $\left[\mathrm{N}^{\prime} / \mathrm{n}\right] / \mathrm{t}$, where $\mathrm{N}^{\prime}$ is the total number of registered double coincidences, $\mathrm{n}-$ number of detector pairs registering double coincidences, $t-$ live measuring time (501 s). In this 32-detector system, the minimum, maximum, arithmetic mean and standard deviation of the background double coincidences counting rates were found to be 0.034 $\left(79.19^{\circ}\right), 0.142\left(37.38^{\circ}\right), 0.066,0.033 \mathrm{cps}$, respectively.

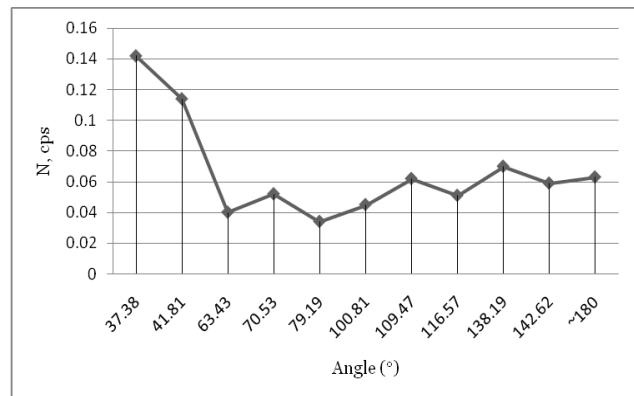

Figure 6. Counting rates of the double background coincidences in the whole energy range at the ARGUS, as a function of the angle between detectors

In general, an average counting rate of background double coincidences at the PRIPYAT-2M spectrometer (Table 4) was found to be higher than in the ARGUS, and was practically the same for the detector pairs at $90^{\circ}$ and $180^{\circ}$.

Table 4. Double background coincidences of the PRIPYAT in the whole energy range ( $\mathrm{N}^{\prime}$ - total number of registered double coincidences, $\mathrm{n}$ - number of detector pairs registering double coincidences)

\begin{tabular}{|cccc|}
\hline \multicolumn{4}{|c|}{ PRIPYAT } \\
\hline $\begin{array}{c}\text { Angle } \\
\left({ }^{\circ}\right)\end{array}$ & $\mathrm{N}^{\prime}$ & $\mathrm{N}^{\prime} / \mathrm{n}$ & $\begin{array}{c}{\left[\mathrm{N}^{\prime} / \mathrm{n}\right] / \mathrm{t}} \\
(\mathrm{cps})\end{array}$ \\
\hline \multicolumn{5}{c}{$\mathrm{t}=498.2 \mathrm{~s}$} \\
$\sim 90$ & 3227 & 268.9 & 0.539 \\
$\sim 180$ & 813 & 271 & 0.544 \\
\hline
\end{tabular}

Double coincidences from monoenergetic sources in the whole energy range are presented in Fig. 7 and Table 5. Registered coincidences are caused by both scattered and photons coinciding randomly.

The minimum, maximum, arithmetic mean and standard deviation of the double coincidences counting rates at the ARGUS spectrometer, coming from monoenergetic sources and photons of different energies (Fig. 7), were found to be $0.974\left(63.43^{\circ}\right)$,

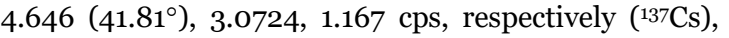
and $0.389\left(63.43^{\circ}\right), 18.706\left(\sim 180^{\circ}\right), 2.794,5.294 \mathrm{cps}$, respectively $(65 \mathrm{Zn})$. The counting rates were calculated after subtraction of background counting rate (b) corresponding to detector pair at the pointed angle.

Detector pairs in the PRIPYAT system (Table 5) at $90^{\circ}$ and $180^{\circ}$ showed just slightly different counting rates.

It can be seen from Fig. 7 and Table 5 , the counting

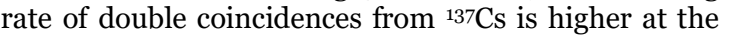
ARGUS (all detector-duplets), while more energetic gamma rays (1116 keV at ARGUS, and $1461 \mathrm{keV}$ at PRIPYAT) caused similar counting rates of few pairs, except for $\sim 180^{\circ}$ duplets and ${ }^{65 \mathrm{Zn}}$ registration. The 
extremely high counting rate of double coincidences in the whole energy range from ${ }^{6} \mathrm{ZZn}$ could be explained by the presence of annihilation ( $511 \mathrm{keV})$ photons, since its $\beta^{+}$decay to the ground state of ${ }^{65} \mathrm{Cu}$ has a probability around $1.5 \%$ (in difference to ${ }^{40} \mathrm{~K}$, whose $\beta^{+}$ decay to the ground state of $4^{\circ} \mathrm{Ar}$ has a probability of $0.001 \%)$.

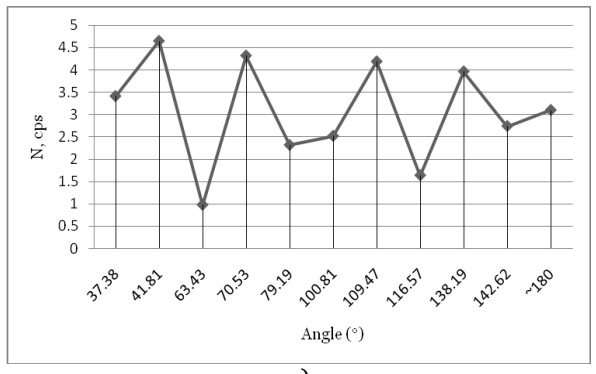

a)

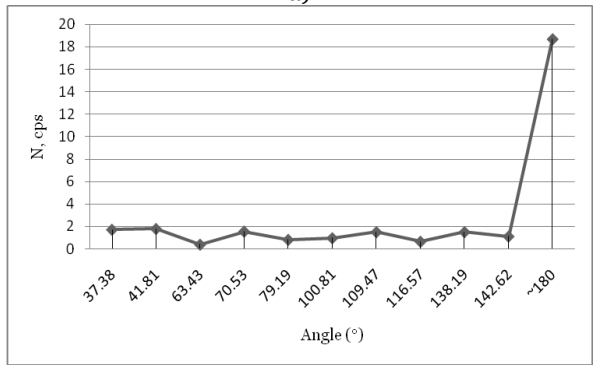

b)

Figure 7. Counting rates of the double coincidences from monoenergetic sources as a function of the angle between detectors at the ARGUS, in the whole energy range: ${ }^{137 \mathrm{Cs}}$ (live measuring time $-50 \mathrm{~s}$ ) (a), $65 \mathrm{Zn}$ (live measuring time $200.5 \mathrm{~s})(\mathrm{b})$

Table 5. Double coincidences (PRIPYAT-2M) from monoenergetic sources (photons with energy $662 \mathrm{keV}$ and $1461 \mathrm{keV}$ ) in the whole energy range

\begin{tabular}{|c|c|c|c|c|}
\hline $\begin{array}{c}\text { Angle } \\
\left({ }^{\circ}\right)\end{array}$ & $\mathrm{N}^{\prime}$ & $\mathrm{N}^{\prime} / \mathrm{n}$ & $\begin{array}{c}{\left[\mathrm{N}^{\prime} / \mathrm{n}\right]} \\
/ \mathrm{t} \\
(\mathrm{cps})\end{array}$ & $\begin{array}{c}\left\{\left[\mathrm{N}^{\prime} / \mathrm{n}\right] / \mathrm{t}\right\} \\
-\mathrm{b} \\
(\mathrm{cps})\end{array}$ \\
\hline $\begin{array}{c}\sim 90 \\
\sim 180\end{array}$ & $\begin{array}{l}7560 \\
1892\end{array}$ & $\begin{array}{c}{ }^{137} \mathrm{Cs} \\
\mathrm{t}=448.8 \mathrm{~s} \\
630 \\
631\end{array}$ & $\begin{array}{c}1.4037 \\
1.406\end{array}$ & $\begin{array}{l}0.867 \\
0.862\end{array}$ \\
\hline $\begin{array}{c}\sim 90 \\
\sim 180\end{array}$ & $\begin{array}{c}12333 \\
3081\end{array}$ & $\begin{array}{c}{ }^{40} \mathrm{~K} \\
\mathrm{t}=405.9 \mathrm{~s} \\
1028 \\
1027\end{array}$ & $\begin{array}{c}2.532 \\
2.53\end{array}$ & $\begin{array}{l}1.993 \\
1.986\end{array}$ \\
\hline
\end{tabular}

Double background coincidences in the energy window corresponding to the photo-peak region $\left(\mathrm{E}_{\gamma} \pm 2 \Delta \mathrm{E}_{\gamma} / \mathrm{E}_{\gamma}\right)$ at ARGUS (measuring times $-1003 \mathrm{~s}$ and $1000 \mathrm{~s}$ for ${ }^{137} \mathrm{Cs}$ and ${ }^{65 \mathrm{Zn}}$, respectively) are presented in Fig. 8, and showed the minimum, maximum, arithmetic mean and standard deviation of 0.003 $\left(63.43^{\circ}\right), \quad 0.0114\left(41.81^{\circ}\right), \quad 0.0074, \quad 0.0029 \mathrm{cps}$, respectively (region $662 \mathrm{keV}$ ), and $0.0056\left(63.43^{\circ}\right)$, $0.0241\left(37.38^{\circ}\right), 0.0148,0.006 \mathrm{cps}$, respectively (region $1116 \mathrm{keV}$ ). Detectors at $\sim 180^{\circ}$ in the $1116 \mathrm{keV}$ region showed counting rate by a factor of 1120 lower than that in Fig. 7. Detector pairs at $90^{\circ}$ and $180^{\circ}$ in the 6-detector system (Table 6), showed similar counting rates in the peak regions.

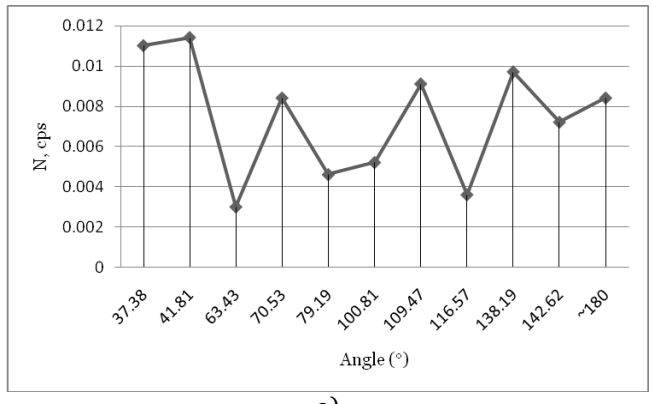

a)

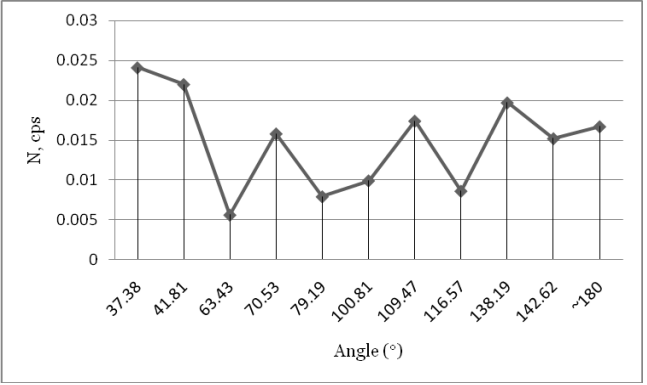

b)

Figure 8. Counting rates of the double background coincidences as a function of the angle between detectors at the ARGUS, in the photo-peak regions: $662 \mathrm{keV}$ (a), $1116 \mathrm{keV}(\mathrm{b})$

Table 6. Double background coincidences in the photo-peak regions (PRIPYAT)

\begin{tabular}{|cccc|}
\hline $\begin{array}{c}\text { Angle } \\
\left({ }^{\circ}\right)\end{array}$ & $\mathrm{N}^{\prime}$ & $\mathrm{N}^{\prime} / \mathrm{n}$ & $\begin{array}{c}{\left[\mathrm{N}^{\prime} / \mathrm{n}\right] / \mathrm{t}} \\
(\mathrm{cps})\end{array}$ \\
\hline \multicolumn{3}{c}{ region $662 \mathrm{keV}$} \\
$\sim 90$ & 493 & 41.083 & 0.0825 \\
$\sim 180$ & 112 & 37.3 & 0.0749 \\
\hline \multicolumn{3}{c}{ region $1461 \mathrm{keV}$} \\
$\sim 90$ & 255 & 21.25 & 0.0426 \\
$\sim 180$ & 64 & 21.33 & 0.0428 \\
\hline
\end{tabular}

The individual spectrum of double coincidences for each detector in the PRIPYAT system generally shows the total number of registered coincidences, which means that the detector registered gamma ray simultaneously (regarding the system time resolution) with another (any one) detector. Such sum spectra (from 2 to 255 channel) of the mentioned detector pairs in the mode of double coincidences and the energy range from 200 to $2000 \mathrm{keV}$ were also analyzed and a number of results are presented in Table 7 . Spectra of ${ }^{137} \mathrm{Cs}$ and ${ }^{40} \mathrm{~K}$ were analyzed after the background subtraction.

As can be seen from Table 7, an average counting rate of background double coincidences from sum spectra of detector pairs, in the energy range from 200 to $2000 \mathrm{keV}$ is around $2 \mathrm{cps}$, in the $662 \mathrm{keV}$ region $0.35 \mathrm{cps}$, and in the $1461 \mathrm{keV}$ region - $0.17 \mathrm{cps}$. Double coincidences from monoenergetic sources in the whole

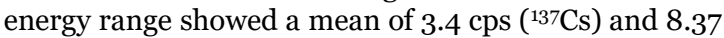
cps $\left({ }^{4} \mathrm{~K}\right)$. An average counting rate of double coincidences in the peak regions was found to be 


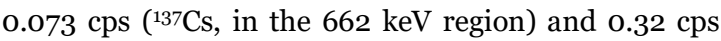
$\left({ }^{\circ} \mathrm{K}\right.$, in the $1461 \mathrm{keV}$ region).

Practically the same counting rate of double coincidences from ${ }^{137 \mathrm{Cs}}$ in the whole energy range (around $3 \mathrm{cps}$ ), was shown by the $\sim 180^{\circ}$ detectors in both spectrometers.

Table 7. Counting rates ( $\mathrm{N}^{\prime} / \mathrm{t}$, cps) from sum spectra of double coincidences (PRIPYAT): N1 -background in the whole energy range, $\mathrm{N} 2$ - background in the $662 \mathrm{keV}$ region, $\mathrm{N}_{3}$ - background in the $1461 \mathrm{keV}$ region; $\mathrm{N}_{4}-{ }_{137 \mathrm{Cs}}$ in the whole energy range, $\mathrm{N}_{5}-{ }_{137} \mathrm{Cs}$ in the peak $(662 \mathrm{keV})$ region; $\mathrm{N} 6-{ }^{\circ} \mathrm{K}$ in the whole energy range, $\mathrm{N} 7-{ }^{\circ} \mathrm{K}$ in the peak $(1461 \mathrm{keV})$ region

\begin{tabular}{|cccccccc|}
\hline Pair & N1 & N2 & N3 & N4 & N5 & N6 & N7 \\
\hline 12 & 1.95 & 0.32 & 0.19 & 3.03 & 0.074 & 7.34 & 0.25 \\
14 & 1.94 & 0.29 & 0.18 & 3.30 & 0.091 & 8.04 & 0.29 \\
15 & 2.05 & 0.31 & 0.21 & 2.81 & 0.085 & 6.78 & 0.19 \\
16 & 2.22 & 0.35 & 0.24 & 3.87 & 0.076 & 9.41 & 0.32 \\
23 & 1.86 & 0.35 & 0.14 & 3.34 & 0.051 & 8.14 & 0.33 \\
25 & 1.97 & 0.36 & 0.17 & 2.73 & 0.074 & 6.87 & 0.26 \\
26 & 2.17 & 0.40 & 0.19 & 3.82 & 0.065 & 9.48 & 0.40 \\
34 & 1.87 & 0.33 & 0.13 & 3.60 & 0.067 & 8.86 & 0.38 \\
35 & 1.99 & 0.35 & 0.15 & 3.12 & 0.069 & 7.59 & 0.29 \\
36 & 2.13 & 0.39 & 0.17 & 4.19 & 0.060 & 10.2 & 0.41 \\
45 & 1.95 & 0.34 & 0.14 & 2.98 & 0.085 & 7.59 & 0.32 \\
46 & 2.15 & 0.38 & 0.18 & 4.08 & 0.076 & 10.2 & 0.46 \\
13 & 1.95 & 0.30 & 0.18 & 3.40 & 0.071 & 8.05 & 0.26 \\
24 & 1.86 & 0.35 & 0.14 & 3.23 & 0.074 & 8.13 & 0.36 \\
56 & 2.27 & 0.39 & 0.21 & 3.59 & 0.076 & 8.94 & 0.35 \\
\hline
\end{tabular}

As mentioned above, background coincidences are the sum of true and random ones. Previous analysis showed that main contributors to the background double coincidences spectra are coinciding photons, which are scattered from crystal to crystal. The data presented here confirm significantly higher counting rates of double coincidences from monoenergetic sources. Leaden collimators later introduced into the ARGUS system generally reduced contribution of the Compton scattering to the spectra of double coincidences (see, for example, [5]). A contribution of random coincidences to the spectra of double coincidences, in particular at the PRIPYAT-2M, will be considered in a further research.

\section{CONCLUSIONS}

The pairs of detectors of the same type and dimensions (NaI (Tl), $150 \mathrm{~mm} \times 100 \mathrm{~mm}$ ) from two multidetector spectrometers with full coverage close to $4 \pi$, 32-crystal (ARGUS) and 6-crystal (PRIPYAT-2M), were analyzed in the light of background double coincidences registration. The results showed a dependence on the angle between detectors, photon energy, radionuclide decay characteristics, confirming that counting rates of double background gamma coincidences should be determined experimentally for the energy regions of interest.

The lowest background double coincidences counting rate in the whole energy range, averaged over all detector pairs at the same angle, was shown by duplets at $79.19^{\circ}$ (at the ARGUS system), while the highest one - detector-duplets at $180^{\circ}$ (at the
PRIPYAT, which generally showed higher counting rate of background coincidences in the whole energy range).

The detector pairs at $63.43^{\circ}$ expressed minimal counting rates in the spectra of double coincidences from monoenergetic sources (an average of $0.389 \mathrm{cps}$ in the whole energy range). The same detector-duplets showed the lowest average counting rate of double background coincidences in the peak-regions (0.003 cps in the $662 \mathrm{keV}$ ( $\left.{ }^{137} \mathrm{Cs}\right)$ region).

While the PRIPYAT detector-duplets at $90^{\circ}$ and $180^{\circ}$ showed similar counting rates of double coincidences from ${ }^{137} \mathrm{Cs}$ and ${ }^{4} \mathrm{~K}$ in the whole energy range (close to $0.9 \mathrm{cps}$ and $2 \mathrm{cps}$, respectively), the highest counting rates in the ARGUS double coincidences spectra of ${ }^{137 \mathrm{Cs} \text { and }}{ }^{6} \mathrm{ZZn}$ have been shown by different detector-duplets (in the case of ${ }^{137 \mathrm{Cs} \text { : }}$ $41.81^{\circ}-4.6 \mathrm{cps}$; in the case of $\left.65 \mathrm{Zn}: \sim 180^{\circ}-18.7 \mathrm{cps}\right)$. The highest counting rate of double coincidences from ${ }^{65} \mathrm{Zn}$ in the whole energy range indicated significant contribution of annihilation photons.

\section{REFERENCES}

1. В. И. Калашникова, М. С. Козодаев, Детекторы элементарных частии, Москва, Россия: Наука, 1966. (V. I. Kalasnikova, M. S. Kozodaev, "Detectors of elemental particles,” Moscow, Russia: Science, 1966.) Retrieved from:

http://www.studmed.ru/kalashnikova-vi-kozodaev-msdetektory-elementarnyh-chastic 301256b8e2b.html\# Retrieved on: Dec. 17, 2016

2. S. K. Andrukhovich, A. V. Berestov et al., "Investigation of orthopositronium $3 \gamma$-decay using a multidetector spectrometer," Nucl. Instrum. Methd. Phys. Res. B, vol. 207, no. 2, pp. 219 - 226, Jun. 2003. DOI: 10.1016/So168-583X (03)00458-0

3. S. Y. F. Chu, L. P. Ekström, R. B. Firestone, Dept. Phys. Univ. Lund, Lund, Sweden, 1999, The Lund/LBNL Nuclear Data Search ver. 2.o.

Retrieved from:

http://nucleardata.nuclear.lu.se/toi/index.asp Retrieved on: Dec. 17, 2016

4. С. К. Андрухович, А. В. Берестов, Ф. Е. Зязюля, Б. А. Марцынкевич, Э. А. Рудак, А. М. Хильманович, Автоматизированная регистрируюшая гаммаустановка совпадений (АРГУС), Минск, Беларусь: AH БCCP, 1986. (S. K. Andrukhovich, A. V. Berestov, F. E. Zyazyulya, B. A. Marcinkevich, E. A. Rudak, A. M. Hil'manovich, Automated registration gamma coincidence system (ARGCS), Minsk, Belarus: AN BSSR, 1986.)

5. N. M. Antović, S. K. Andrukhovich, A. V. Berestov, "A contribution of the Compton scattered radiation from Mn-54 to double gamma coincidences spectra at the 32-detector system," in Proc. Conf. RAD 2014, Niš, Serbia, 2014, pp. $127-130$.

Retrieved from:

http://www.rad-

conference.org/helper/download.php?file=../pdf/Proce edings\%20RAD\%202014.pdf

Retrieved on: Jan. 14, 2017

6. N. M. Antović, S. K. Andrukhovich, A. V. Berestov, "Background in a test of detecting "cooperative" parapositronium annihilation by the 32-crystal spectrometer ARGUS," in Proc. Conf. RAD 2015 , Budva, Montenegro, 2015, pp. 123 - 127. 
Retrieved from:

http://www.rad-

conference.org/helper/download.php?file=../pdf/Proce edings\%20RAD\%202015.pdf

Retrieved on: Jan. 14, 2017

7. С. К. Андрухович, А. В. Берестов, В. И. Гутко, А. М. Хильманович,

Высокочувствительные многодетекторные гамма спектрометры ПРИПЯТЬ, Минск, Беларусь: АН БССР, 1995. (S. K. Andrukhovich, A. V. Berestov, V. I. Gutko, A. M. Hil'manovich, High sensitive multidetector gamma spectrometers PRIPYAT, Minsk, Belarus: AN BSSR, 1995.)

8. Н. М. Антовић, С. К. Андрухович, А. В. Берестов, "Ефикасност детекције фотона $662 \mathrm{keV}$ 32-детекторским системом типа Crystal Ball - са и без колиматора," у Зборнику 27. Симпозијума Друштва за заштиту од зрачења Србије и Црне Горе, Врњачка Бања, Србија, 2013, стр. 435 - 438.
(N. M. Antovic, S. K. Andrukhovich, A. V. Berestov, "Detection efficiency of the $662 \mathrm{keV}$ photons by the 32-Crystal Ball detector system - with and without collimators," in Proc. 27th Symp. of the Radiation Protection Society of Serbia and Montenegro, Vrnjačka Banja, Serbia, 2013, pp. 435 - 438.)

Retrieved from:

http://dzz.org.rs/wp-content/uploads/2013/o6/2013Vrnjacka-Banja.pdf

Retrieved on: Jan. 14, 2017

9. N. Antovic, N. Svrkota, "Measuring the radium-226 activity using a multidetector $\gamma$-ray coincidence spectrometer," J. Environ. Radioactiv., vol. 100, no. 10, pp. $823-830$, Oct. 2009

DOI: 10.1016/j.jenvrad.2009.06.003

PMid: 19577345 